\title{
AN ORGANISATIONAL CULTURE MODEL TO PROMOTE CREATIVITY AND INNOVATION
}

\author{
ELLEN MARTINS \\ Organisational Diagnostics \\ NICO MARTINS \\ Department of Industrial Psychology \\ University of South Africa
}

\begin{abstract}
The aim of the study was to determine what type of organisational culture would support creativity and innovation in an organisation. A new model was developed and compared with the theoretical model. Similarities, differences and new perspectives emerged. The factors trust relationship, working environment, management support and customer orientation on an operational level presented shifts in emphasis in the new model. The trust relationship in particular indicated that trust manifests in openness and sincerity. Trust influences both employee support for change and the probability of successful change, which influence the degree to which creativity and innovation are stimulated and promoted.
\end{abstract}

\section{OPSOMMING}

Die doel van die studie was om te bepaal watter tipe organisasiekultuur kreatiwiteit en innovasie in 'n organisasie sal stimuleer. ' $n$ Nuwe model is ontwikkel en met die teoretiese model vergelyk. Ooreenkomste, verskille en nuwe perspektiewe het aan die lig gekom. Die faktore vertrouensverhouding, werkomgewing, bestuursondersteuning en kliëntegeoriënteerdheid op ' $\mathrm{n}$ operasionele vlak was klemverskuiwings in die nuwe model. Spesifiek die vertrouensverhouding het daarop gedui dat vertroue manifesteer in openlikheid en opregtheid. Vertroue beinvloed beide werknemers se steun vir verandering en die waarskynlikheid van suksesvolle verandering, wat die mate waarin kreatiwiteit en innovasie gestimuleer en bevorder word, sal beinvloed.

For most organisations change is inevitable. Organisational cultural issues are becoming increasingly important and a source of a strategic competitive advantage. Organisational changes usually promote and intensify competitiveness, as they require dramatic changes in strategy, technology, working systems and management style, among others. These changes require an in-depth analysis of values, beliefs and behaviour patterns that guide day-to-day organisational performance. Creativity and innovation have a role to play in this change process. The topic of organisational culture often presents two contradictory images. The first is of culture as "the glue that holds the organisation together", and the second regards it as a central part of the change process (Denison, 2001, p. 347). According to Read (1996, p. 223) post-industrial organisations of today are knowledge-based organisations and their success depends on creativity, innovation, discovery and inventiveness. The importance of creativity and innovation is emphasised as follows by Zaltman et al. (in West \& Farr, 1990, pp. 3-4): "The importance of new ideas cannot be overstated. Ideas and their manifestations as practices and products are the core of social change."

In the midst of change, organisations and leaders are trying to create an institutional framework in which creativity and innovation are accepted as basic cultural norms. It has become clear that "the unwritten rules of the game" (the norms of behaviour) and shared values influence morale, performance and the application of creativity and innovation in many different ways. Deal and Kennedy (1982, p. 164) stated that openness and trust in the change process influence whether and how change occurs. Senge, Kleiner, Roberts, Ross, Roth and Smith $(1999$, p. 44) support this statement by pointing out that openness (developing a genuine spirit of inquiry and trust) often plays a critical role in profound change processes. Furthermore compelling new ideas help people think and act in new ways. In this respect there is a definite need to understand how organisational culture should be dealt with in order to promote creativity and innovation as part of constant change. This need was already identified by Schuster (1986, X) in 1986.

Requests for copies should be addressed to: $N$ Martins, Department of Industrial Psychology, UNISA, Po Box 392,UNISA, 0003.E-mail: martin@unisa.ac.Za
Authors like Johnson (1996, pp. 9,11), Judge, Fryxell and Dooley (1997, p. 73), Pienaar (1994, pp. 3-35), Shaughnessy (1988, p. 5), Tesluk, Faar and Klein (1997, p. 27) and Tuskman and O'Reilly (1997, p. 27) all agree that organisational culture is a contributing factor to the degree to which creative and innovative behaviour is found among employees in an organisation. Michela and Burke (2000) argue that quality and innovation in organisations are inextricably intertwined with organisational culture.

There seems to be little agreement in the literature as to what type of organisational culture will promote creativity and innovation (Judge et al., 1997, p. 73). There also seems to be a paradox: Organisational culture can promote the creativity and innovation that are necessary to be competitive and successful, but, on the other hand, it can also be an obstacle to creative and innovative behaviour (Glor 1997, p. 44, Tushman $\&$ O'Reilly 1997, pp. 31,35). The question is: What type of organisational culture will support creativity and innovation in an organisation?

Several researchers (Ahmed 1998, Filipczak 1997, Judge et al., 1997, Nÿstrom 1990, O’Reilly 1989, Pinchot \& Pinchot 1996, Tesluk et al., 1997) have worked on identifying values, norms and assumptions involved in promoting and implementing creativity and innovation. Very few empirical studies, especially quantitative research, appear to have been carried out to support the research findings, but several values, norms and beliefs have been identified by researchers like Judge et al. (1997), Nÿstrom (1990) and O'Reilly (1989) in their empirical research. The purpose of the research presented here is to identify, operationalise, measure and describe the determinants of organisational culture that might influence creativity and innovation.

In order to synthesise the cultural values and norms that influence creativity and innovation, as found in the literature, the integrated, interactive model shown in figure 1 was created (Martins, 2000). This model is based on the work of Martins $(1989,1997)$ which describes organisational culture and the importance of leadership in creating an ideal organisational culture that influences organisational behaviour. 
Figure 1: Influence of Organisational Culture on Creativity and Innovation (Preliminary model based on literature study)

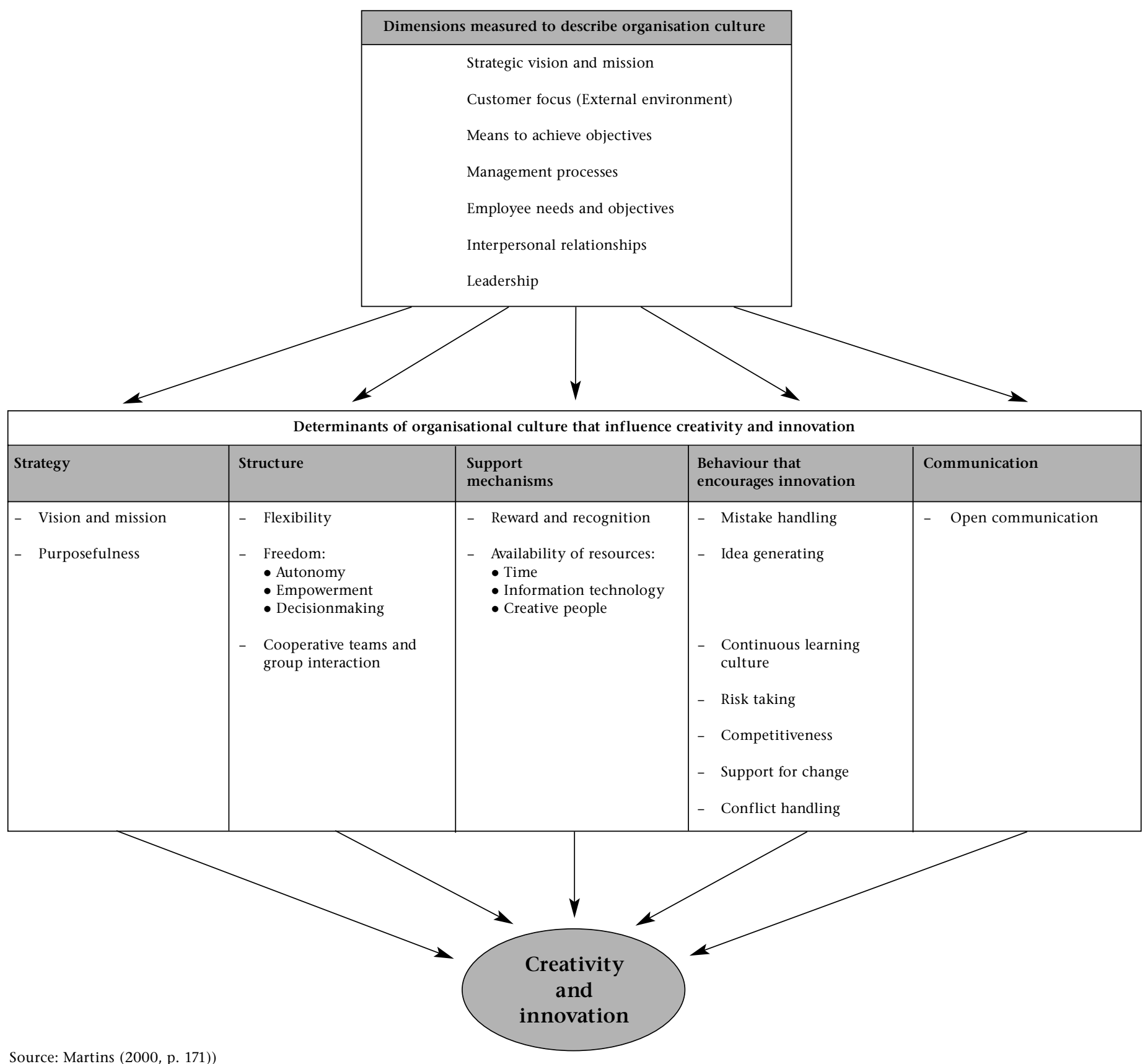

Source: Martins (2000, p. 171)

The model developed by Martins (1989) to describe organisational culture was based on the work of Edgar Schein and draws on open systems theory [originally developed by Ludwig van Bertalanfy in 1950, and adapted by several authors like Kast \& Rosenzweig, 1985 and Kreitner \& Kinicki, 1995]. The systems approach offers a holistic approach, but also emphasises the interdependence between the different subsystems and elements in an organisation (French \& Bell, 1995). The organisational systems model explains the interaction between organisational subsystems (goals, structure, management, technology and psycho-sociological). The complex interaction which takes place on different levels between individuals and groups, and also with other organisations and the external environment, can be seen as the primary determinants of behaviour in the work place. Based on the dimensions that describe organisational culture (figure 1), Martins (2000) identified and synthesised the determinants of organisational culture that influence creativity and innovation as found in the literature.
The purpose of Martins's (2000) research was to determine empirically through quantitative research, the determinants that influence creativity and innovation from a cultural perspective, and to compare the findings with the model based on the literature study (figure 1).

\section{METHOD}

\section{Sample}

It was mentioned previously that creativity and innovation play an important role in the change process and that the degree to which change occurs in organisations is influenced by the organisational culture. Against this background it was decided to conduct the study in a service-orientated organisation that was going through a transformation and change process. It was also decided to do the study in one organisation only, since the organisational culture varies from one organisation to another (Hellregiel, Slocum \& Woodman, 1998, p. 546 \& Shaughnessy, 1988, p. 7). 
The total population of 286 employees received questionnaires and $188(70.1 \%)$ questionnaires were returned and analysed. The largest group of participants were female (73.8\%) and $26.2 \%$ were male. Afrikaans speaking participants were the largest group (57.7\%) followed by English speaking (21.4\%), African speaking (19.7\%) and other language speaking participants (1.2\%). Most respondents (46.8\%) had longer than 10 years' service with the organisation, $42.5 \%$ had between 4 and 10 years of service, $8.6 \%$ between 1 and 3 years and $2.2 \%$ less than one year of service.

\section{Measuring instrument}

The instrument developed by Martins $(1989,1997)$ to describe organisational culture was used, since it follows a holistic approach that covers all facets of an organisation which could influence the culture. A factor analysis previously carried out on this instrument indicated a reliability (Cronbach Alpha) of 0,933 . The internal consistency of the dimensions was between 0,655 and 0,932 .

\section{Procedure}

The existing data from the survey administered to describe the organisational culture, as part of the transformation and change process, was used. Based on the theoretical model (figure 1) and the literature study, variables that might influence the degree to which creativity and innovation occur in an organisation - were selected. The original questionnaire consists of 95 questions and 46 of these were identified as having a possible influence on the creativity and innovation in an organisation.

According to Hair, Anderson, Tatham and Black (1995, p. 373) the size of the sample should be at least 100 . The general rule is that there should be at least five times more observations than the number of variables that are analysed. The highest observation per variable will ensure that the factors obtained from the analysis are not sample specific and therefore ungeneralisable. Although there were more than 100 respondents in this research, the proportion was four-to-one (188 respondents and 46 variables).

\section{Statistical analysis}

The statistical calculations of the study/investigation were done by the researcher, using Hintze's (1997) Number Cruncher Statistical System (NCSS).

An explorative approach (where no prior restriction or estimate of the number of components to be extracted from the data, is set) was followed in order to do a factor analysis (Nunnally, 1978 p.331). The purpose of the factor analysis was to determine which variables (questions identified at face value) strongly correlate with each other, in order to determine a pattern of correlations between variables (Kervin, 1992, p. 507). The factor analysis allowed the researcher to determine the construct validity of the items (i.e. do the items measure what they are supposed to measure?) (Mouton \& Marais 1990, p. 70).

An item analysis using the Cronbach Alpha coefficient was used to determine the internal reliability of the items in the "newly discovered" factors. The purpose was to determine how accurately the items measure the factors and consequently if they could be regarded as reliable, that is if they would produce the same results when the measurement is repeated (Sekaran, 1992, p. 284).

\section{RESULTS}

The first proof analysis of the component factor analysis, with the factor selection method set as an eigen value of 1,00 as the cut-off point, did not produce a satisfactory factor structure. The variables were divided into 13 factors with only three or four questions each, which made interpretation difficult.
A second proof analysis of the component factor analysis was done using percentage of eigen value as the criterion for factor selection. The best factor structure was obtained when 50 percent of the variance was met. According to Hintze's NCSS User's Guide II (1997, p. 1245) and Hair et al. (1995, p. 378 ) the factors should correspond with at least 50 percent of the variance.

The results of the number of factors are displayed in figure 2 .

\section{Figure 2: Eigen VALUES OF FACTORS FOR FACTOR SELECTION} (AFTER VARIMAX ROTATION)

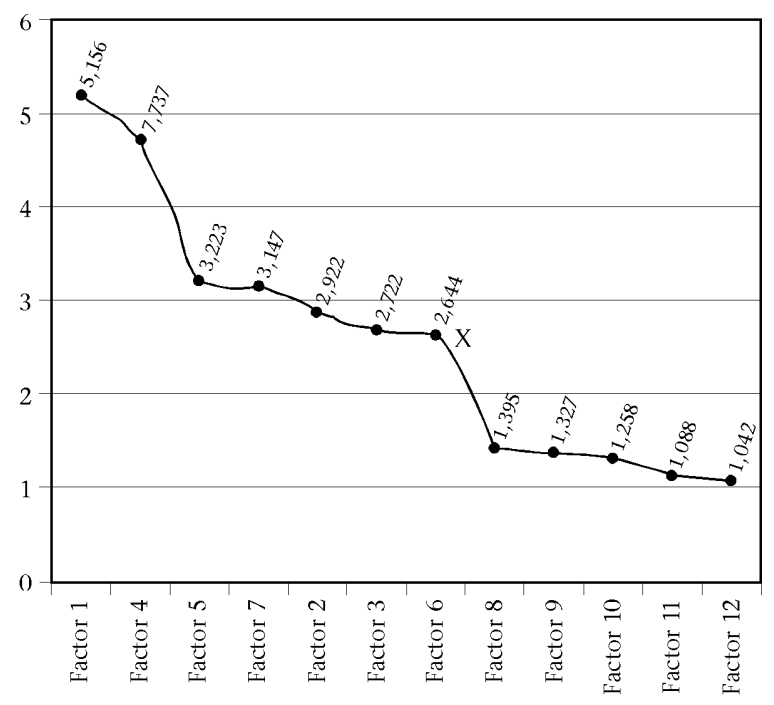

For factor selection an eigen value greater than one was used. Only seven factors were postulated and within reason those with an eigen value close to one were eliminated.

Cartell's scree test, which is a rough indication of how many factors should be retained (Hintze, 1997, p. 1167), also indicated that there is a drastic decline in eigen values (see $\mathrm{x}$ in figure 2) after factor six, which consequently confirms that seven factors are an acceptable postulation.

The percentage of eigen values for the first 12 factors after VARIMAX rotation are displayed in table 1 .

TABLE 1

Percentage of eigen values after varimax rotation

\begin{tabular}{cccc}
\hline Factor & Eigen value & $\begin{array}{c}\text { Percentage of } \\
\text { Eigen value }\end{array}$ & $\begin{array}{c}\text { Cumulative } \\
\text { percentage }\end{array}$ \\
\hline 1 & 5,156 & 10,97 & 10,97 \\
2 & 2,922 & 6,22 & 17,19 \\
3 & 2,722 & 5,79 & 22,98 \\
4 & 4,373 & 9,30 & 32,28 \\
5 & 3,223 & 6,86 & 39,14 \\
6 & 2,644 & 5,63 & 44,77 \\
7 & 3,147 & 6,70 & 51,46 \\
\hline 8 & 1,395 & 2,97 & 54,43 \\
9 & 1,327 & 2,82 & 57,25 \\
10 & 1,258 & 2,68 & 59,93 \\
11 & 1,088 & 2,31 & 62,25 \\
12 & 1,042 & 2,22 & 64,46 \\
\hline
\end{tabular}


It appears that the first seven factors measure up to fifty percent of the variance. The Number Cruncher Statistical System gave a summary of the factor structure after VARIMAX rotation and only seven factors were postulated, which once again confirms that it is an acceptable postulation.

It will be noted that the factors are not ranked from highest to lowest eigen value. The reason for this is that the results of rotated factors are postulated, which produces a clearer factor interpretation than the initial factor postulation.

\section{Conceptual naming of factors}

Conceptual naming of the different factors produced the names as displayed in table 2 .

\section{TABLE 2}

\section{NAMing OF FACTORS}

\begin{tabular}{ll}
\hline Factor & Naming \\
\hline Factor 1 & Strategy \\
Factor 2 & Purposefulness \\
Factor 3 & Trust relationship \\
Factor 4 & Innovation behaviour \\
Factor 5 & Working environment \\
Factor 6 & Customer orientation \\
Factor 7 & Management support \\
\hline
\end{tabular}

The factor analysis was done with the selected items and 0,40 was used as the cut-off point for factor loading per item. A total of five items had a loading of lower than 0,40 and it was decided to eliminate them as these variables appeared weakly represented. Six items loaded high on two different factors and it was decided to include the item in the factor in which it was conceptually best suited.

The items that were used to identify the influence of culture on creativity and innovation explain 14,196 percent of the total variance of the total measuring instrument, which is satisfactory. This percentage is the total communality of all the factors together.

Item analysis with Cronbach Alpha

The internal reliability of the factors is displayed in table 3 .

TABLE 3

RESULTS OF RELIABILITY OF FACTORS

\begin{tabular}{ll}
\hline Factor & Cronbach Alpha \\
\hline Factor 1 Strategy & 0,863246 \\
Factor 2 Purposefulness & 0,703082 \\
Factor 3 Trust relationship & 0,680553 \\
Factor 4 Innovation behaviour & 0,838808 \\
Factor 5 Working environment & 0,770422 \\
Factor 6 Customer orientation & 0,700476 \\
Factor 7 Management support & 0,642976 \\
\hline
\end{tabular}

The reliability coefficient varies between 0,643 and 0,863 . These measurements may be regarded as acceptable (reliable) since they are all above 0,6. Two of the measurements are above 0,8 , which can be regarded as good (very reliable).
Discussion of results

The empirical study indicated that a new model can be developed to explain the influence of organisational culture on creativity and innovation in this service-orientated organisation. The model appears in figure 3 .

The results of the factor analysis showed that seven factors were postulated that would promote creativity and innovation in this service-orientated organisation. Each factor will be discussed briefly with reference to the literature based model (figure 1).

\section{Strategy}

The factor "strategy" postulated in the empirical research supports the preliminary theoretical model to a large extent in that a strategy that leads to creativity and innovation in an organisation is described in the vision and mission as a customer - focused marketing orientation. This orientation also includes active research into the needs of existing and potential customers with a view to promoting creativity and innovation (Martins, 2000, p. 225).

The core values should be integrated with activities and results and employees should be informed about the core values through the vision and mission of an organisation. An example of a vision that focuses on creativity and innovation would be the following: "Our company will innovate endlessly to create new and valuable products and services and to improve our methods of producing them" (Lock \& Kirkpatrick 1995, p. 119)

Reaction to change and management's knowledge in leading the organisation into the future did not form part of the determinant "strategy" in the preliminary model, but can be interpreted as offering support to the strategy followed in a service organisation (Martins, 2000, pp. 225-226). This is supported by Shin and McClomb (1998, p. 1) who claim that the type of top management who are most inclined to make innovation happen are those who have a clear vision of future direction and of the operation of organisational change and creativity.

\section{Purposefulness}

Although purposefulness formed part of the determinant "strategy" in the preliminary model, it was postulated as a separate determinant for an organisational culture that supports creativity and innovation (Martins, 2000, p. 226)

The employees' understanding of the vision and mission should have an influence on the implementation thereof (Lock \& Kirkpatrick 1995, p. 119). The extent to which creativity and innovation occur in an organisation can only be determined if the vision and mission statements mention creativity and innovation. In other words the question about employees' understanding of the vision and mission does not make it possible to determine the extent to which creativity and innovation occur in the organisation; only that an understanding of the vision and mission will influence their implementation (Martins, 2000, p. 227).

Employees' involvement in identifying outputs and participating in reaching goals and objectives will also influence the extent to which creativity and innovation take place and this is supported by Terblanche (1990, p. 283) (Martins, 2000, p. 227).

The availability of measurable standards of the results that need to be achieved by individuals also seems to play a role in purposefulness and the promotion of creativity and innovation. Lock and Kirkpatrick (1995, p. 120) claim that it is necessary to state specific quantitative and time-related objectives for creative services and products.

Stating 'stretch objectives' such as generating 30 percent of all income from products that are younger than four years, and 
Figure 3: MODEL OF THE INFLUENCE OF ORGANISATIONAL CULTURE ON CREATIVITY AND INNOVATION

\begin{tabular}{|l|}
\hline Dimensions measured to describe organisation culture \\
\hline Strategic vision and mission \\
Customer focus (External environment) \\
Means to achieve objectives \\
Management processes \\
Employee needs and objectives \\
Interpersonal relationships \\
Leadership
\end{tabular}

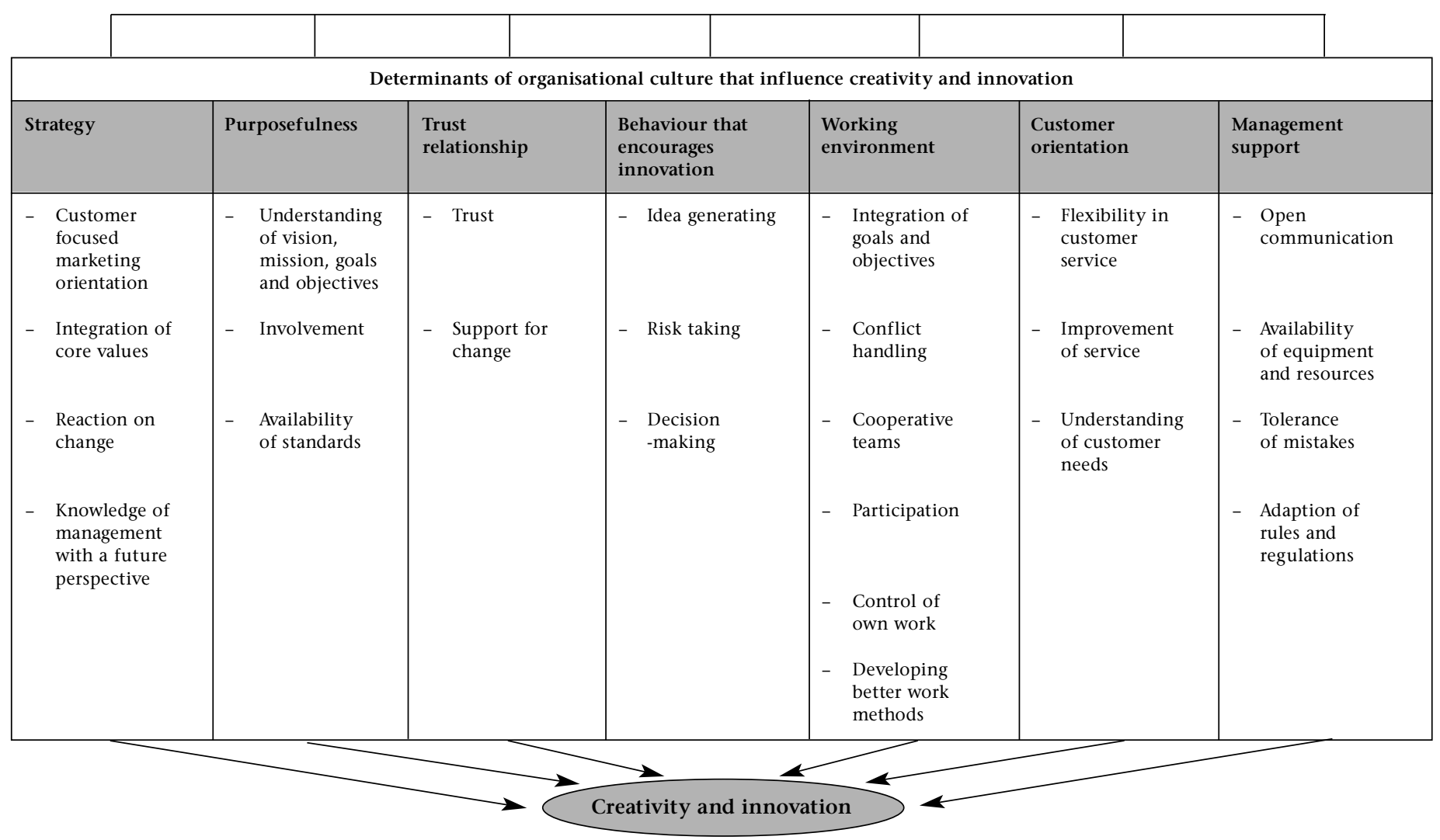

Source: Martins (2000, p. 23))

measuring results against set standards, should lead to improved creativity and innovation (Filipczak 1997, p. 36, Martins, 2000, p. 151). Senge et al. (1999. p. 82) state that stretch goals are one of the four key lessons that force employees to let go of existing conventional wisdom and become creative and innovative as they design new approaches.

\section{Trust Relationship}

In the preliminary model the trust relationship between management and employees and between employees was discussed under open communication, with the focus on "openness". In the empirical research the focus seems to have moved to trust. This new focus is supported by Barret (1997, p. 15) who claims that an organisational culture which is based on trust that manifests in openness and sincerity, is an organisational culture that supports creativity and innovation. Many researchers argue that trust is crucial to an organisation's success in an increasingly complex and rapidly changing environment (Dunford, 1999; Martins, 1999).

The trust relationship in an organisation will be strengthened when management and employees act openly toward each other. People will feel emotionally safe and this should lead to an atmosphere in which creativity and innovation can flourish (Filipczak, 1997, p. 35, Frohman \& Pascarella, 1990, p. 21). Management should also trust the process of innovation from lower to higher levels by taking note of the potential of innovative projects. In contrast, employees should also trust managers when they intervene (Shaw, 1997, p. 120). In other words a high degree of innovation can be achieved if the organisational culture created by management, promotes a high degree of trust (Martins, 2000, p. 229).

Support for change formed part of behaviour that encourages innovation in the preliminary model. The willingness of employees to adapt to change (new ways of doing things) formed part of the value "flexibility" as part of the structure. The factor postulation in the empirical research included these aspects in the trust relationship factor. It creates the impression that it will be easier for people to adapt to change and new ways of doing things if there is a good trust relationship amongst employees (including management). This statement is supported by Shaw $(1997$, p. 3) who claims that trust amongst employees should increase the probability of successful change, in other words that employees will replace old practices with new practices. 
It appears that support for change and trust relate to each other and both will influence the degree to which creativity and innovation are stimulated and promoted in an organisation.

Behaviour that encourages innovation

In the preliminary model idea generating and risk taking also formed part of the determinant "behaviour that encourages innovation", which corresponds to the empirically postulated factor of behaviour that encourages innovation.

Idea generating involves aspects such as encouragement to generate ideas, selling good ideas, management's giving credit for ideas, encouragement to take initiative and to find new ways of solving problems.

Management should create values that support risk taking and should demonstrate through their actions that risk taking and experimenting are acceptable behaviour (Arad, Hanson \& Schneider, 1997, p. 48, Khalil, 1996, p. 35, Robbins, 1996, p. 736). At the same time it is important that risk taking should be calculated and balanced to allow employees freedom in taking risks, but also to increase the possibility of success by creating a culture that allows for moderate risk taking. Management should realise that innovative employees are largely motivated by the possibility of success rather than the results of success (Aber, 1996, p. 5, Frohman \& Pascarella, 1990, p. 22).

Decision-making formed part of the determinant "structure", under the value "freedom" in the preliminary model. Shattow's (1996, p. 4) claim that participation in decisionmaking could lead to (among other things) more ideas being generated, quicker decisions being taken and ideas being converted into outputs, possibly explains why this item forms part of this newly postulated factor, namely behaviour that encourages innovation.

\section{Working environment}

The determinant "working environment" seems to focus on employees in the organisation and the way in which work takes place in the working environment as part of the organisational culture.

When compared with the preliminary model, it becomes clear that the items were extracted from three different determinants, namely strategy, innovation behaviour and organisational structure (freedom of decision-making and empowerment, team cooperation and group interaction).

The actualisation of personal goals and objectives in pursuing organisational goals and objectives seems to relate to creativity and innovation. This corresponds to Terblanche's (1990, p. 283) statement that the integration of personal and organisational goals creates a culture for creativity.

Conflict handling in the working environment should be handled constructively to promote creativity and innovation (O'Reilly, 1989, p. 14). According to Robbins (1997, p. 169) some conflict is absolutely necessary for a group to perform effectively.

Another factor that has an influence on the degree to which creativity and innovation take place in an organisation is cooperative teams. This is supported by Arad et al. (1997, p. 47), Covey (1993, p. 4) and Tushman and O'Reilly (1997, p. 116).

The degree to which the working environment can be described as participative forms part of this new determinant, while in the preliminary model (figure 1) it formed part of decision-making and empowerment. One can conclude that if the environment is participative, employees will probably have the freedom to generate new ideas and participate in decision-making, which forms part of empowerment (Martins, 2000, p. 234).

According to Tarlton (1996, p. 16) a feeling of having control over ones own work is necessary to promote creativity.
Developing better work methods formed part of support for change in the preliminary model as such development would indirectly imply changes taking place. In the new postulation developing better work methods seems to fit in well with the working environment in which employees find themselves. The action of developing better work methods would promote creativity and innovation.

\section{Customer orientation}

This factor focuses on understanding the needs of internal and external customers, improving customer service and flexibility in customer service. For many organisations, fostering creativity and innovation is essential to their ability to offer high quality products and services (Hellriegel, Slocum \& Woodman, 2001, p. 436).

It is interesting to note that the factor postulation clearly distinguishes between a market-orientated strategy (as discussed under strategy) and this factor which focuses on a customer orientation on the operational level.

Although Nÿstrom (1990, p. 156) did not emphasise customer orientation as a core value of the most innovative department in this research, this factor supports his finding that reaction to customer needs should be flexible.

\section{Management support}

In the preliminary model the role of management was emphasised in each of the determinants. However, in the new postulation of the empirical study, it appears that management has a specific supporting role in promoting creativity and innovation.

Open communication between employees, management and different departments as a determinant of organisational culture that would support creativity and innovation is supported by authors like Filipczak (1997, p. 36), Lock and Kirkpatrick (1995, p. 20) and Shattow (1996, p. 47). Bresnahan (1997, p. 52) emphasises the role of management by pointing out that "open doors" foster innovation. Furthermore, Ahmed (1998, p. 36) points out that face to face communication promotes innovation.

Availability of equipment and resources is dependant on management's support. The degree to which equipment and resources are available improves or detracts from the likelihood of there being creativity and innovation. This is supported by authors such as Khalil (1996, p. 35) and Bresnahan (1997, pp. 54-56).

The degree to which employees are blamed for mistakes is an indication of managers' tolerance of mistakes made. This tolerance role of managers in promoting or hindering creativity and innovation is emphasised by Tushman and O’Reilly (1997, p. 115).

The supporting role of managers in adapting rules and regulations is related to their role in supporting change, which will have an influence on creativity and innovation. In other words, the degree to which managers support the adaptation of rules and regulations to keep up with change will have an influence on creativity and innovation.

\section{DISCUSSION}

The results of the comparisons between the preliminary model and the model that evolved from the empirical study have indicated interesting similarities, differences and new perspectives. Strategy and behaviour that encourage innovation were identified as determinants in both models. The factors called trust relationship, working environment, management support and customer orientation on an operational level were interesting shifts in emphasis in the new model. Although the role of management was emphasised in each determinant in the preliminary model, a specific management support role in terms 
of communication, tolerance of mistakes, flexibility in adapting rules and regulations and support in availability of equipment and resources emerged.

Although the new model cannot be regarded as an ideology, it helps shed light on the determinants of culture that influence creativity and innovation.

The model is applicable in one organisation only and will have to be tested in other organisations to claim generalisability of the model.

Furthermore it was not possible in the empirical study to test (measure) all the determinants that were identified in the literature study. However, this is a possibility for further research and would be a step in the direction of a complete model.

Areas that need to be addressed are certain aspects of purposefulness (e.g. values that support quality rather than effectiveness, freedom of employees to achieve goals at their own discretion, the effect of personal and organisational goals and objectives on creativity and innovation, goals that focus on innovation, promotion of creativity and innovation as an outcome of the understanding of the vision and mission), cooperative teams (the way in which groups and teams interact with each other and the impact on creativity and innovation, effective functioning of teams), support mechanisms (availability of time to be creative and innovative, recruitment, selection and maintaining creative people, rewards and recognition), behaviour that encourages innovation (learning culture, competitiveness), speed of decision-making, and values like flexibility, freedom and autonomy.

In conclusion it appears that compiling an instrument that specifically measures a creative and innovative organisational culture shows great promise if all aspects that could not be tested in this research are included. This will enable organisations to determine the degree to which the culture of a specific organisation supports creativity and innovation, which is essential in being successful and adapting to changing circumstances.

\section{REFERENCES}

Aber, J.W. (1996). Building a risk management culture. Bankers Magazine, 179, 3-6.

Ahmed, P.K. (1998). Culture and climate for innovation. European Journal of Innovation Management, 1 (1), 30-43.

Arad, S., Hanson, M.A. \& Schneider, R.J. (1997). A framework for the study of relationships between organizational characteristics and organizational innovation. The Journal of Creative Behaviour, 31 (1), 42-58.

Barret, R. (1997). Liberating the corporate soul. HR Focus, 74 (4), 15-16.

Bresnahan, J. (1997). The elusive muse. CIO, 11 (2), 50-56.

Covey, S.R. (1993). Innovation at four levels. Executive Excellence, $10(9), 3-5$.

Deal, T.E. \& Kennedy, A.A. (1982). Corporate cultures: the sites and rituals of corporate life. Reading, MS: Addison-Wesley.

Denison, D. (2001). Organisational culture: Can it be a key lever for driving organisational change? In C.L. Cooper, S. Cartwright \& P.C. Earley (Eds.). The international handbook of organizational culture and climate. New York: John Wiley \& Sons.

Dunford, R. (1999). If you want loyalty get a dog! In S.R. Clegg, E. Ibarra-Colorado \& R. Bueno (Eds.). Global management: Universal theories and local realities. London: Sage, 68-82.

Filipczak, B. (1997). It takes all kinds: Creativity in the work force. Training, 34 (5), 32-40.

French, W.L. \& Bell, C.H. (1995). Organizational development: Behavioural science interventions for organizational improvement (5th ed.). Englewood Cliffs, NJ: Prentice Hall International.
Frohman, M. \& Pascarella, P. (1990). Achieving purpose-driven innovation. Industry Week, 239 (March 19), 20-24.

Glor, E.D. (1997). Encouraging public sector innovation. Optimum, 27 (2), 41-48.

Hair, J.F., Anderson, R.E., Tatham, R.L. \& Black, W.C. (1995). Multivariate data analysis with readings (4th ed.). Englewood Cliffs, NJ: Prentice Hall.

Hellriegel, D., Slocum, J.W. \& Woodman, R.W. (1998). Organizational behavior (8th ed.). Cincinnati, OH: South Western College.

Hellriegel, D., Slocum, J.W. \& Woodman, R.W. (2001). Organizational behavior (9th ed.). Australia: South-Western College.

Hintze, J.L. (1997). Number Cruncher Statistical System user's guide I \& II: NCSS 97 statistical system for windows. Kaysville, UT: Number Cruncher Statistical Systems.

Johnson, M.M. (1996). Finding creativity in a technical organization. Research Technology Management, $3 a$ (5), 9-11.

Judge, W.Q., Fryxell, G.E. \& Dooley, R.S. (1997). The new task of $\mathrm{R} \& \mathrm{D}$ management: Creating goal-directed communities for innovation. California Management Review, 39 (3), 72-85.

Kast, F.E. \& Rosenzweig, J.E. (1985). Organization and management: A systems and contingency approach (4th ed.). New York: McGraw-Hill.

Kervin, J.B. (1992). Methods for business research. New York: HarperCollins.

Khalil, O.E.M. (1996). Innovative work environments: The role of information technology and systems. Sam Advanced Management Journal, 61 (3), 32-36.

Kreitner, R. \& Kinicki, A. (1995). Organizational behaviour (3rd ed.). Chicago: Irwin.

Lock, E.A. \& Kirkpatrick, S.A. (1995). Promoting creativity in organizations. In C.M. Ford \& D.A. Gioia (Eds.). Creative action in organizations: Ivory tower visions and real world voices. London: Sage.

Martins, E.C. (2000). Die invloed van organisasiekultuur op kreatiwiteit en innovasie in ' $n$ universiteitsbiblioteek/The influence of organisational culture on creativity and innovation in a university library. Unpublished Master's thesis. University of South Africa, Pretoria.

Martins, N. (1989). Organisasiekultuur in ' $n$ finansïle instelling/Organisational culture in a financial institution. DPhil-thesis. University of South Africa, Pretoria.

Martins, N. (1997). Elandsrand Goldmine: organisational culture survey. Johannesburg.

Martins, N. (1999, July). Managing employee trust during transformation. Paper presented at VI European Congress of Psychology, Rome.

Michela, J.L. \& Burke, W.W. (2000). Organizational culture and climate in transformations for quality and innovation. In N.M. Ashkanasy, C.P.P. Wilderom \& M.F. Peterson (Eds.). Handbook of organisational culture and climate. California: Sage.

Mouton, J. \& Marais, H.C. (1990). Basiese begrippe: metodologie van die geesteswetenskappe. Pretoria: Raad vir Geesteswetenskaplike Navorsing.

Nunnally, J.C. (1978). Psychometric theory (2nd ed.). New York: McGraw-Hill. (McGraw-Hill series in psychology).

Nÿstrom, H. (1990). Organizational innovation. In M.A. West \& J.L. Farr (Eds.). Innovation and creativity at work: Psychological and organizational strategies. Chichester: Wiley, 143-161.

O'Reilly, C. (1989). Corporations culture and commitment: Motivation and social control in organizations. California Management Review, Summer, 9-25.

Pienaar, H. (1994). Die kreatiewe en innoverende universiteitsbiblioteek/The creative and innovation university library. DPhil-thesis, University of Pretoria, Pretoria.

Pinchot, E. \& Pinchot, G. (1996). Five drivers for innovation. Executive excellence, 13 (1), 9-10. 
Read, W.H. (1996). Managing the knowledge-based organization: Five principles every manager can use. Technology Analysis and Strategic Management, 8 (3), 223-232.

Robbins, S.P. (1996). Organizational behaviour: Concepts, controversies, applications (7th ed.). Englewood Cliffs, NJ: Prentice-Hall.

Schuster, F.E. (1986). The proven connection between people and profits. New York: Wiley.

Sekaran, U. (1992). Research methods for business: A skill-building approach (2nd ed.). New York: Wiley.

Senge, P., Kleiner, A., Roberts, C., Ross, R., Roth, G. \& Smith, B. (1999). The dance of change: The challenges of sustaining momentum in learning organizations. A fifth discipline resource. London: Nicholas Brealy.

Shaw, R.B. (1997). Trust in the balance: Building successful organizations on results, integrity and concern. San Francisco: Jossey-Bass. (The Jossey-Bass business and management series).

Shattow, M. (1996). Out of the blue. Electric perspectives, 21 (3), 44-54.
Shaughnessy, T.W. (1988). Organizational culture in libraries: Some management perspectives. Journal of Library Administration, 9 (3), 5-10.

Shin, J. \& McClomb, G.E. (1998). Top executive leadership and organizational innovation: An empirical investigation of nonprofit human services organizations (HSOs). Administration in Social Work, 22 (3), 1-21.

Terblanche, J. (1990). Kreatiwiteit in die organisasie/Creativity in the organisation. South African Journal of Library and Information Science, 58 (3), 282-286.

Tesluk, P.E., Faar, J.L. \& Klein, S.R. (1997). Influences of organizational culture and climate on individual creativity. The Journal of Creative Behavior, 31 (1), 21-41.

Tushman, M.L. \& O'Reilly III, C.A. (1997). Winning through innovation: A practical guide to leading organizational change and renewal. Boston, MASS: Harvard Business School Press.

West, M.A. \& Farr, J.L. (1990). Innovation at work. In M.A. West \& J.L. Farr (Eds.). Innovation and creativity at work: Psychological and organizational strategies. Chichester: Wiley, 3-13. 